\title{
Truth, Fact and Value: Recovering Normative Foundations for Sociology
}

\author{
Reha Kadakal
}

Published online: 2 October 2013

(C) Springer Science+Business Media New York 2013

Can sociology have normative presuppositions? Is the purpose of sociology to study society as it is or how it ought to be? Can we task sociology with serving moral and ethical ends? If so, are there universal categories by means of which we can define what constitutes a good society? Or are all such categories in the end but particular constructs unique to particular cultures and traditions, and hence bound by relativism? The history of the social sciences has proven these to be profoundly formidable questions to answer. In fact, far from providing a systematic conceptual framework, contemporary social theory in its current state consists of diverse and often contradictory theoretical standpoints and ethical presuppositions that make any single approach to normative foundations of social science appear to be limited, partial and ultimately untenable.

Philip S. Gorski's "Beyond the Fact/Value Distinction: Ethical Naturalism and the Social Sciences" raises some of these fundamental questions, as his central concern is whether sociology can help us tackle the question of good society. ${ }^{1}$ Arguing against the conventional understanding of the fact/value distinction in the social sciences, Gorski not only reminds us that "values inflect facts in...fundamental and less tractable ways" but also argues that values are fact-laden, have an experiential basis, and hence are open to empirical investigation. Accordingly, Gorski advocates for ethical naturalism, a brand of moral realism that conceives "an independent territory" between facts and values, "a middle kingdom of moral facts...containing discoverable truths about the good life and good society."2

\footnotetext{
${ }^{1}$ Gorski, Philip S. "Beyond the Fact/Value Distinction: Ethical Naturalism and the Social Sciences." See in this volume.

2 ibid., p. 1.
}

R. Kadakal $(\bowtie)$

Social Sciences Collegiate Division, The University of Chicago,

5845 S Ellis Ave., Chicago, IL 60637, USA

e-mail: rkadakal@uchicago.edu
The goal of ethical naturalism is, among other things, to discover ethical truths, which exist independently of the human mind, as a matter of social scientific knowledge. ${ }^{3}$ Such an approach, Gorksi hopes, would also counter some of the ethically self-contradictory implications of moral relativism - contradictions that become fully clear when it comes to questions of harm and depriving human beings of the material conditions of a dignified life. One fundamental premise of ethical naturalism, in Gorski's view, is an Aristotelian notion of "flourishing" that emphasizes the importance of the social order as the source of human well-being. In so arguing, he also points out an irony in sociology's trajectory as a discipline, for almost all of the classical theorists of sociology, according to Gorski, with the exception of Max Weber, were ethical naturalists. It is on these premises that Gorski offers us a reading of some of the major figures in philosophy and classical sociological theory, from Hume and Kant to Marx, Weber, and Durkheim, to take contemporary sociology "beyond the fact/value distinction" and onto a renewed normative foundation.

This is a worthy goal, and an undertaking long overdue in sociology as a discipline, as well as a refreshing attempt to counter not only positivist scientism but also the discourses of cultural and moral relativism. Not only do I agree with the main argument of ethical naturalism, that is, that the questions of good life and good society can, and in fact should be the subject of the social sciences; I also argue that, when it first emerged as a new discipline in late nineteenth century Europe, sociology was one such attempt at a normatively founded social science.

Nevertheless, the question of good society necessitates more than a rethinking of the fact/value distinction. As is well known, the fact/value distinction in sociology is only an extension of another and more fundamental question, one that concerns theory of knowledge, namely the condition of possibility of a form of knowledge that is objectively true and

\footnotetext{
3 ibid., p. 11
} 
independent of subjective evaluations. With ethical naturalism, Gorski seems to suggest that in showing the factual basis of judgments, values gain objective validity. This proposition, however, assumes that objectivity in sociology can be reduced to positivist conceptions of knowledge, where what is objectively true is that which remains after subjective factors are eliminated, or "the residual theory of truth," as Adorno once called it. ${ }^{4}$ It is my contention, however, that for Durkheim and Weber, as well as for Marx, what constitutes the substance of good society, or the ethical question, and what is knowledge, are inseparable questions in sociological investigation.

In what follows, I will scrutinize some of the assertions of ethical naturalism that Gorski offers, in order to assess to what extent ethical naturalism can provide the normative foundations of sociology. After reflecting on the notion of "flourishing" in Gorski's argument, I will explore to what extent Durkheim, Weber, and Marx are compatible with ethical naturalism. Both Durkheim and Weber in their respective ways strived to offer a reflective theory of knowledge, one that would put human subjectivity at the foundation of scientific knowledge. Sociology as a discipline followed a rather different trajectory than that which its founding fathers intended, and has increasingly adopted an empiricist understanding of truth built on the positivist model of the natural sciences. The most clear outcome of this development is the fact/value distinction as it is conventionally understood. Perhaps the most profound effect of this positivist trajectory has been the disappearance of the notion of good society from the purview of social theory. I propose that we should rethink the foundations of our discipline for a new theory of knowledge in order to reclaim the original project of sociology and move beyond contemporary relativist understandings of truth onto a new footing for normative social science. ${ }^{5}$

\section{On Flourishing}

Can the notion of "flourishing" provide a normative foundation for social science? Although the Aristotelian notion of "flourishing" deployed by Gorski appears to be very promising in tackling the questions of good society, on the one hand, and moral relativism on the other, it might in fact be of little help in taking on the fundamental implications of a definition of "good society" for the social sciences. The question of what kind of social order would be ideal for human flourishing can only be answered through preconceived notions of what it means to be human, of the meaning of existence, and of what

\footnotetext{
${ }^{4}$ Adorno, Theodor. Hegel: Three Studies. Trans. Shierry Weber Nicholsen. Cambridge: MIT Press, 1993. p.7

${ }^{5}$ For a more thorough discussion on this point, see Kadakal, Reha. "Subjectivity, Consciousness and Determination and the Search for a Conception of Truth in Social Theory." Ph.D. Dissertation. New School For Social Research, 2008.
}

"flourishing" consists in for human beings conceived as such. That is to say, it is not the notion of "flourishing" itself, but a concept of what such "flourishing" consists in for human beings that is central to answering what constitutes good society. From the outset, it is obvious that, for instance, an Evangelical Christian, an Islamic Fundamentalist, and an atheist would give fundamentally different and often contradictory definitions of the content and criteria of such "flourishing"- all of which would fundamentally differ from that of Aristotle's.

Furthermore, the notion of "flourishing" is even more problematic when it is taken to serve as a normative foundation for sociology. And this is not because Aristotle, who was a great philosopher would, unfortunately for us, make a terrible sociologist if we were to extend some of the central criteria of his moral philosophy to understand the constitution of society. For instance, as Gorski already points out, we would not consider acceptable, nor justifiable, some of his conceptions about women or the ideal social order. ${ }^{6}$ What is important to note is that this is not because Aristotle was a prejudiced man and misconceived human beings. It is rather because of the fact that the moral and ethical ends of human life, and notions of what constitutes good society are categories with their own historicity. As Durkheim put it, "the man that we try to be is the man of our times and of our milieu." "Put differently, the content of "flourishing," what such flourishing consists in for human beings, cannot be unproblematically derived from any moral philosophy, nor from an ethical naturalist notion of human being, without simultaneously raising some fundamental questions of validity for these very claims.

How can we establish normative foundations for social science then? What are the conditions of possibility of such knowledge with ethical ends? Can we conceive of what constitutes good society without falling back on naive empiricism in the form of a fact/value distinction on the one hand, and its total trivialization by moral relativism on the other?

In fact, this very question of the validity of truth-claims, factual and normative, was one of the foundational questions of sociology. Not only were sociology's founding fathers concerned, as Gorski points out, with the question of good society at a very fundamental level; such a concern is also reflected in their respective methodologies and in their theories of knowledge - theories that underlie sociology as a discipline. For both Durkheim and Weber, the question of the good and the question of truth were imminently interrelated, and as such, were central to each author's theoretical concerns.

A thorough account of their social theories is beyond the scope if this paper, but in what follows, I will make a few brief

\footnotetext{
${ }^{6}$ Gorski, "Beyond the Fact/Value Distinction: Ethical Naturalism and the Social Sciences." p. 13

${ }^{7}$ Durkheim, Emile. Sociology and Philosophy. New York: The Free Press, 1974. p. 68
} 
points as to the way Durkheim, Weber, and Marx each conceived the question of good society within the bounds of the theories of knowledge that underlie their sociological theories.

\section{Durkheim's Paradigm}

As Gorski points out, Durkheim argued for the existence of moral facts. For Durkheim, however, moral facts refer to something quite different than facts as conceived in positivism. Durkheim makes the case that sociology can solve philosophy's problems, especially the problem of judgment. ${ }^{8}$ In The Elementary Forms of Religious Life, Durkheim offers a sociological paradigm that is both a theory of knowledge and a theory of society at the same time. Through a sociological analysis of organizationally prime - and not primitive - cases, Durkheim demonstrates how society is only possible through moral regulation. ${ }^{9}$ On the other hand, he also shows how basic notions upon which our judgments are founded (which, since Aristotle came to be referred to as "categories of understanding," including time, space, cause, and substance, to name a few) "not only...come from society but the very things they express are social." $"$ By offering a theory of the social origin of the categories of understanding, which form the "permanent framework of mental life," 11 in a truly neoKantian fashion, Durkheim indeed offers a new framework to address the problems of knowledge as well as of morality, one that answers challenges of both empiricism and idealism. Neither position is tenable for Durkheim, since the former reduces reason to experience, and hence leads to irrationalism by making reason, its universality, and its necessity, disappear, whereas the latter offers no explanation at all. ${ }^{12}$

For Durkheim, "society constitutes a moral authority that confers 'an obligatory character' to moral precepts." ${ }^{\text {13 }}$ Not only can the object of morality never be an individual interest; in fact, for Durkheim, the individual in itself does not constitute a moral end! The object of morality is society: "Morality begins with membership in a group, whatever that group may be." ${ }^{14}$ However, this should not be interpreted as subjugating the individual to the moral standard prevailing in a given historical moment. How do we draw practical consequences from this theory of society? Durkheim makes a distinction between "society as it appears to itself" and "society as it is or is really becoming." 15 Society as it appears to itself, that is, the

\footnotetext{
${ }^{8}$ ibid., p. 80

${ }^{9}$ Durkheim, Emile. The Elementary Forms of Religious Life. New York:

The Free Press, 1995. p. 5

10 ibid,. p. 441

${ }^{11}$ ibid., p.441

12 ibid., pp. $13-18$

${ }^{13}$ Durkheim, Sociology and Philosophy, p. 38

14 ibid., p. 37

15 ibid., p. 38
}

consciousness that society has of itself, as expressed in general moral opinion, may in fact be an inadequate view of underlying reality. The real condition of society and general moral opinion are not necessarily identical. A science of morality, then, is not a science of moral opinion. Rather, a study of moral facts is a study of the state of society, and especially for modern society, it is a study of society in the process of becoming. The task of sociology for us, then, is to go beyond how society sees itself or expresses itself in prevailing moral opinion, no matter how popular it may be at a given time, and discover society as it is. Whereas the study of moral opinion is an invaluable source of information to understand social and moral aspirations and sentiments, there is more to sociology than just "throwing a little light upon the tendencies of public opinion."16 The object of the study of moral facts is "the condition of society, not social opinion, [and] the role of reason is to help the age to be more aware of itself, its needs and its sentiments." ${ }^{.17}$ The science of moral facts, for Durkheim, is one such application of reason toward that end. The following statement by Durkheim puts this very powerfully:

"Socrates expressed, more clearly than his judges, the morality suited to his time. It would be easy to show that, as a result of the transformation of the old society based on the gens and the consequent disturbance of religious beliefs, a new morality and religious faith had become necessary in Athens." 18

However-and this is crucial-such a science of moral facts always operates within history: "It would be equally simple to demonstrate that this aspiration toward a new formulation was not felt by Socrates alone, but that there was already a powerful current represented by the attitudes of the Sophists. It is in this sense that Socrates was ahead of his time while at the same time expressing its spirit." 19

For Durkheim, it is through a science of moral facts that society can arrive at a fuller and higher consciousness of itself and can "direct its changes." ${ }^{20}$ Sociology, then, is society's self-understanding. For Durkheim, however - and this is the point I would like to emphasize - such an application of reason, to understand the moral order and "direct its changes," does not correspond to a moral faculty. "If bearing the seal of science is usually enough today to gain a sort of privileged credibility, that is because we have faith in science." ${ }^{21}$ It does not consist in an application of a "moral ideal," the "true ideal" to be put forward against "that which society follows at each moment of its history." 22 For Durkheim, this would amount to apriorism, which could only

\footnotetext{
$\overline{16}$ ibid., pp. 63-64

17 ibid., p. 64

18 ibid., pp. 64-65

19 ibid., p.65

20 ibid., p. 66

${ }^{21}$ Durkheim, Elementary Forms, p. 439

${ }^{22}$ Durkheim, Sociology and Philosophy, p. 66
} 
be an "arbitrary affirmation" of moral ideals and not of facts. The normative foundations of social science, therefore, do not consist in a true ideal to be applied to the moral order to direct it. As Durkheim has it,

"The Roman had his ideal of perfection which was related to the constitution of the Roman city, just as ours is related to the structure of contemporary society. It is a gross illusion to believe that we have freely conceived it in our conscience." ${ }^{, 23}$

\section{Weber and the Question of Meaning}

Weber's sociology cannot be readily fit into an ethical naturalist framework, as Gorski notes. However, Weber did have fundamental concerns for normative questions in his theory of society. What he was not convinced of, however - and for good reasons - was the notion that normative judgments, i.e., what is a good society, could be arrived at though factual truths. It is important to note, however, that whereas Weber argued in his methodological writings that the premises of scientific knowledge must be objective, rational and valuefree, he also made the case, with a great insight into modern forms of knowledge, that the meaning of such truths, that is, how we interpret them, and their implications in the world for us, are always evaluative and normative. It was this normative nature of truth that, for Weber, could not be legitimately derived from the sciences, since scientific knowledge was already premised on the meaning of such truths. As Weber put it, "the means available to our science offer nothing to those persons to whom this truth is of no value."24

For Weber, accordingly, the solution to ethical questions cannot be derived from scientific truths. This did not mean that they cannot be derived at all! Assessing the validity of values is not a matter of science. Science can successfully examine and evaluate the means for attaining certain ends, but such scientific deliberations assume already settled ends. Only a political discourse on normative standards can convey, reflect on, and problematize values themselves. Thus, in "Science as Vocation" Weber exposes an irony of modern society that the immense development of scientific knowledge is helpless in resolving value disputes, including the truthvalue of its own self evidence.

Still, how is it that Weber was not convinced by the possibility of factually based normative truths? Weber's conviction that they could not be derived from the sciences must be understood in terms of the theory of knowledge - the theory of knowledge through which both Weber and Durkheim developed their respective sociological theories and addressed their concerns for the condition of possibility

\footnotetext{
23 ibid., p. 68

${ }^{24}$ Weber, Max. The Methodology of the Social Sciences. Trans. Edward A. Shils and Henry A. Finch. New York: Free Press, 1949. p. 110
}

of normative foundations of sociological knowledge. The main themes of Weber's sociology, such as the disenchantment of the modern world, the culturally rooted valuepremises of modern science and knowledge, and rationality are the products of this theory of knowledge. The central question that runs throughout these themes is the question of the meaning of modern life for the modern subject. In a time of unprecedented social change, Weber's sociology made the case for the pivotal role of subjectivity in the turns and swings of history, and revealed how values impart meaning to history itself. More than being an attempt to explain history through culture, Weber's sociological paradigm expresses his striving to bridge the gap between truth and subjectivity. I suggest understanding the source of this gap in terms of the particular way in which the neo-Kantians conceptualized Kant's critical philosophy. In the case of Weber's social-scientific method, its conceptual framework and its underlying conception of truth were molded by this very theory of knowledge.

Both Weber and Durkheim, then, advocated social science as a means for society to reflect upon itself, its processes, and its institutions. From this perspective, such theoretical study can help us to derive the practical consequences of moral orders, but can never enable us to define true ideals as such. Neither Durkheim nor Weber draw resignation from such a conclusion, however. For Durkheim, it is such a science that helps society to reflect upon itself; as he notes, in making use of "what scientific observations are at our disposal...It is true that we run a risk, but that is inevitable." ${ }^{25}$ Likewise, Weber was equally open to what the future might have to offer, that is, the future was "open to human will and resolution." 26 The fact that they come close to one other in pointing out, in their respective ways, the limits of science in defining truth is not due to their pessimism but rather to the contours of their common theory of knowledge. It is this theory of knowledge, which is also the foundation of sociology as a science, that in fact created an unbridgeable gap between the conditions of possibility of knowledge, and the possible definition of what constitutes a good society - that is, between the possibility of knowing society, and the task of defining a society true to the ends of human beings.

On this account, no definition of what constitutes a good society can be derived from science itself as long as we remain within the bounds of neo-Kantian theory of knowledge. I suggest that in order to overcome the naively conceived fact/ value distinction as it currently stands in the social sciences in general, and in sociology in particular, rather than demonstrating how values are influenced by facts, and hence truth value, we must radically rethink the very distinction itself; not in

\footnotetext{
${ }^{25}$ Durkheim, Emile. Sociology and Philosophy. New York: The Free Press, 1974. p. 67

${ }^{26}$ Roth, Guenther, and Wolfgang Schluchter. Max Weber's Vision of History. Berkeley: University of California Press, 1979. p.201
} 
order to prove how facts leak into values, thus casting the latter as fact-based rather than constructed, as Gorski proposes, but in order to show the immanent relation between facts and values, between what is true and what is good. Only then can a middle kingdom of moral facts provide the normative foundations of social science. ${ }^{27}$ The formulation of normative foundations for sociology requires a new theory of knowledge.

\section{Marx and Historicity}

The questions of objective knowledge, of the fact/value distinction, and of good society in sociology are theoretical and methodological questions that emerged when the social and cultural sciences started to replace idealist philosophy in the nineteenth century. The neo-Kantian theory of knowledge was one answer to the problems of objective knowledge and to the elimination of subjectivity by positivism, but ultimately cannot ground a sociological definition of good society. Marx's critical engagement of Hegel's objective idealism can offer us an important alternative route. The basic premises of this social theory emerged out of Marx's critical writings on Hegel's' Idealism in the 1840 s. In his reading of early Marx, Gorski brings up the notion of "species being" to make the case for ethical naturalism within the sociological heritage. ${ }^{28}$ Indeed, one can delineate two main themes in Marx's early critique of Idealism. First, there is a Feuerbachian approach to Idealism that centers around the concepts of alienation, labor, and species-being. Second is the idea that human practical activity is a socially constituting activity for human beings. I am of the conviction that the extent of Marx's Feuerbachianism in his early writings might be overstated. In fact, I suggest that in Marx's social theory, "species-being" plays a different analytical role than that of defining human nature in terms of inherent capacities as Gorski would have it. In Marx's early critique of Idealism, "species being" underscores the socio-historical dimension of human practical activity. Such socio-history was captured earlier with the notion of "species-being" by Feuerbach, whose goal was the critique of the idealist account of religion. More specifically, "species-being" was Feuerbach's answer to Hegel's conception of Christianity as "unhappy consciousness." In his critique, Feuerbach showed how religion and other institutions had been perceived by Idealsim to have an autonomous, independent, and universal existence. According to Feuerbach, however, such autonomy and independence, as well as the universal existence of religion, were in fact impressions attributed to these

\footnotetext{
${ }^{27}$ Cf. Gorski, "Beyond the Fact/Value Distinction: Ethical Naturalism and the Social Sciences."

${ }^{28}$ Gorski, "Beyond the Fact/Value Distinction: Ethical Naturalism and the Social Sciences." p. 16
}

institutions in order to fulfill the needs of the individual as a real, living being. For Feuerbach: "Man has his highest being, his God, in himself; not in himself as an individual, but in his essential nature, his species. No individual is an adequate representation of his species, but only the human individual is conscious of the distinction between the species and the individual; in the sense of this distinction lies the root of religion." 29

In Marx's social theory, "species-being" has an entirely different connotation than that of Feuerbach's. In his critique of Feuerbach, Marx states that the determinate processes of society cannot simply be explained by a reference to nature, as in Feuerbach, and must rather be grasped rationally. Marx's concept of "species-being," accordingly, brings into analytical picture the dimension of social life that is "not true to itself." However, in Marx, the reference point of such "untruth" of contemporary society is not nature as in Feuerbach, nor can it be captured through a naturalistic conception of human beings and their make up and needs. Rather, for Marx the "untruth" of existing social forms must be explained in reference to human practice. Likewise, Marx's critique of Hegel's Idealism as a "logical, pantheistic mysticism" expands on a similar point, that is, Idealism makes the Idea the subject, and turns the real subjects into moments of the Idea. ${ }^{30}$ If we revisit Marx's reconstruction of the rational core of Hegel's idealism, we find the foundations of a reflective social theory that includes both a radical critique and a critical transformation of the significant categories of objective idealism. Such a rational core consists in the conceptual foundations of a normative social theory able to engage social reality, and to reflectively engage its own categories at the same time. ${ }^{31}$

For Marx, Hegel's Phenomenology contains, albeit in estranged form, "the critical elements of whole spheres such as religion, the state, civil life, etc.," ${ }^{\prime 32}$ that point to the process of objectification (a process that conveys alienation and then the transcendence of this alienation) which, for Marx, represents a model for comprehending human beings as an outcome of their own practice. This idea finds its mature formulation later in Contribution and Capital as a theory of social constitution that reveals the commodity form as the total processes of capitalist society. In showing how the commodity form became the model on which modern society is organized, Marx's

\footnotetext{
${ }^{29}$ Feuerbach, Ludwig. The Essence of Christianity. Trans. George Eliot. Buffalo: Prometheus Books, 1989. p. 281

${ }^{30}$ Marx, Karl. Critique of Hegel's 'Philosophy of Right'. Trans. Annette Jolin and Joseph O'Malley. Cambridge: Cambridge University Press, 1970. p. 7

${ }^{31}$ Cf. Postone, Moishe. Time, Labor, and Social Domination: A Reinterpretation of Marx's Critical Theory. New York: Cambridge University Press, 1993

${ }^{32}$ Marx, Karl. The Economic and Philosophic Manuscripts of 1844. Trans. Martin Milligan. Ed. Dirk J. Struik. New York: International Publishers, 1964. p. 176
} 
critical theory also shows human practical activity as the selfconstituting activity of human beings.

This account of Marx, however, is substantially different from that of the traditional Marxist orthodoxy. At the risk of being redundant, it is worth stating that while traditional Marxism purports to be a "real social science," its unreflective theorizing selectively extracts theoretical concepts out of Marx's historical categories, and hence attributes universal validity to historically specific theoretical concepts. This fallacy of orthodox Marxism becomes even more catastrophic when it is carried from the realm of the "true" to the realm of the "good," resulting in what is ultimately a subjectivemoralist stand, one that reduces the question of good society to the particular moral standpoint of a collectivist construct such as the proletariat.

What I am advocating for here is a social theory with a reflective methodology that is cognizant of its own historicity, a social theory that allows us to distinguish society as such from its current form, and to demonstrate the possibility of good society without subscribing to any metaphysics of morals, including that of Kant. This reflective theorizing should circumvent the problems of a neo-Kantian theory of knowledge - problems that continue to undercut the normative foundations upon which sociology was founded.

\section{Toward a Reflective Social Theory}

To go back to our initial question, then: is it possible to normatively ground sociology and define good society without falling back on a naively conceived fact/value distinction or idealist or positivist metaphysics? Can we have normatively grounded systematic knowledge without morally and ethically subjective presuppositions? With what must sociology begin? ${ }^{33}$ Here I will only stipulate some general provisions for a reflective social theory, as points to consider when navigating through the intersecting questions of truth, fact, value, and good society.

First, following in the footsteps of the founding fathers, sociology must ground truth in concrete social reality rather than in philosophical metaphysics. We already have before us the historical development of consciousness and society that points to such a concrete grounding. As a matter of the history of social theory, European thought in the second half of the nineteenth century was a turning point, when theory of knowledge replaced metaphysics and constituted human subjectivity as central to its conception of truth. From where we stand as moderns, perhaps the most important outcome of this historical and conceptual process is the emergence of autonomous

\footnotetext{
$\overline{33}$ cf. Hegel, Georg W. F. Hegel's Science of Logic. Trans. A. V. Miller. New York: Humanity Books, 1998.
}

subjectivity as a central category in our thought as well as in social reality. Reverting back to metaphysically grounded notions of truth is possible only if we choose to overlook this historical and conceptual transformation. The task of sociology is to conceive of good society as a matter of concrete social relations rather than through metaphysically conceived presuppositions of objective knowledge, facts, and values. I argue that the theoretical sources of such a direction for social theory are to be found in one of the fundamental assertions of Hegel's idealism, namely the idea that consciousness itself is embodied in all aspects of reality. True knowledge and true society, in other words, cannot be confined to the epistemological presuppositions of objectivity, subjectivity, and the fact/value distinction. In Hegel's system, moments of the subjective and the objective are mediated by one another. It is these processes of mediation that sociology must comprehendprocesses that society itself, that is, the subject character of society as an object, brings about. ${ }^{34}$ In doing so, however, sociology must circumvent any form of sociological reductionism that subsumes consciousness as a function of social or economic classes, status groups or ideologies - a paradigm of sociology of knowledge ${ }^{35}$ that in effect dismisses conceptions of truth as the ephemeral reflection of practical relations.

A critical reconstruction of the rational core of Hegel's idealism offers us conceptual foundations for a reflective social theory. Not only can such an approach go beyond the fact/value distinction; it also eliminates the need for transcendental subjectivity to ground a possible conception of good society, or a collective subject (such as the proletariat) to justify a partial, moral, or ideological standpoint. Instead, this new social theory of knowledge as a theory of society can demonstrate the possibility of a good society beyond the totality of current social relations, but can also reflect on consciousness itself as one of the moments of historical relations. It is such a social theory of knowledge, I maintain, that can help us to understand the question of good society as a mediation of autonomous subjects, social forms of consciousness, and social and cultural processes. It is the task of social theory to provide us with tools to define good society, and to demonstrate its historicity, as well as the historicity of its own thought, without relativizing truth.

Reha Kadakal is a Lecturer at the University of Chicago, Social Sciences Collegiate Division. Currently he is revising his book manuscript on truth in social theory.

\footnotetext{
${ }^{34}$ See Adorno, Theodor. Introduction to Sociology. Stanford: Stanford University Press, 2000.

${ }^{35}$ See Heller, Agnes. A Theory of History. London: Routledge \& Kegan Paul, 1982
} 